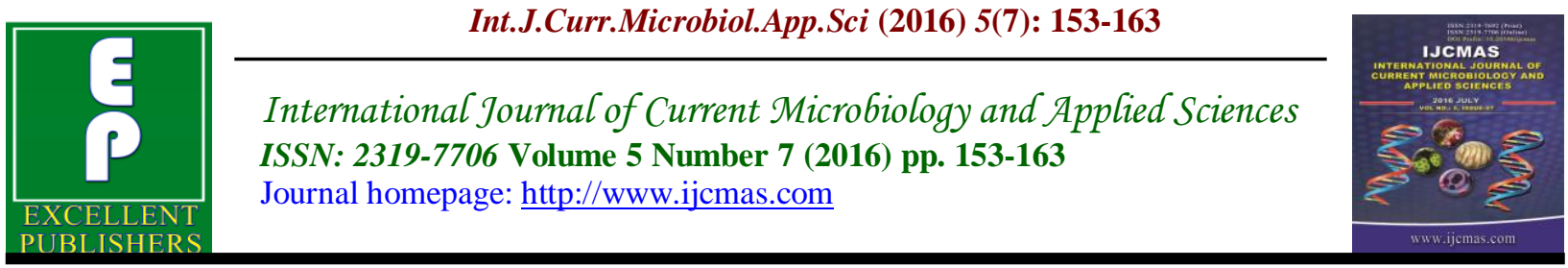

Original Research Article

http://dx.doi.org/10.20546/ijcmas.2016.507.015

\title{
Isolation, Identification and Characterization of Keratinolytic Streptomyces coelicoflavus
}

\author{
R.S. Jadhav ${ }^{1 *}$, D.D. Karad ${ }^{2}$ and S.W. Kulakrni ${ }^{3}$ \\ ${ }^{1}$ Department of Microbiology, Vishwasrao Naik Art's, Commerce and Baba Naik Science \\ Mahavidyalaya, Shirala 415408, Dist-Sangli (M.S.) India. \\ ${ }^{2}$ Research Department of Microbiology, Shriman Bhausaheb Zadbuke Mahavidyalaya, Barshi \\ 413 401, Dist-Solapur(M.S.) India. \\ ${ }^{3}$ Research Department of Microbiology, Shri Shivaji Mahavidyalaya, Barshi 413 401, \\ Dist-Solapur (M.S.) India \\ *Corresponding author
}

\begin{tabular}{|c|c|}
\hline & A B S T R A C T \\
\hline Keywords & Fourteen isolates were obtained from poultry and beam house region soils of Sangli \\
\hline $\begin{array}{l}\text { Actinomycetes, } \\
\text { Streptomyces, } \\
\text { Keratinase, } \\
\text { Feather meal. }\end{array}$ & $\begin{array}{l}\text { coelicoflavus. The ability of Streptomyces coelicoflavus to utilize chicken feather } \\
\text { as a substrate was tested. Crude extract of keratinase enzyme from feather meal } \\
\text { broth was used for characterization. It was found that maximum enzyme } \\
\text { activitywas } 49 \mathrm{U} / \mathrm{ml} \text {. Crude keratinase was optimally active in the pH range from } 7.5\end{array}$ \\
\hline Article Info & $\begin{array}{l}\text { to } 8 \text { and at temperatures from } 35^{\circ} \mathrm{C} \text { to } 40^{\circ} \mathrm{C} \text {. The various divalent metal ion were } \\
\text { tested. } \mathrm{Ca}^{++} \text {and } \mathrm{Zn}^{++} \text {were found to enhance the activity whereas } \mathrm{Mg}^{++}, \mathrm{Cu}^{++} \cdot \mathrm{Mn}^{++}\end{array}$ \\
\hline $\begin{array}{l}\text { Accepted: } \\
\text { 08 June } 2016 \\
\text { Available Online: } \\
10 \text { July } 2016\end{array}$ & $\begin{array}{l}\text { inhibit the enzyme activity. Also reducing agents and inhibitors were tested. } \\
\text { Reducing agent such as Dithiothreitol (DTT) inhibit the enzyme activity whereas } \\
\text { sodium sulphide, SDS increases the enzyme activity. 1,10phenanthroline and } \\
\text { EDTA were increases the enzyme activity. }\end{array}$ \\
\hline
\end{tabular}

\section{Introduction}

Feather is almost pure keratin protein consisting of amino acids (Mukesh kumar, 2012). In nature, keratin occurs mainly in the form of hair, horn, nail and cornified tissue. Worldwide about 24 billion chickens are killed annually and totally about 8.5 billiontonnes of poultry feather are produced (Agrahari, 2010). According to recent report India's contribution alone is about 250 million tonnos (Agrahari, 2010).
Feather contains over $90 \%$ protein. The main component being $\beta$-keratin, a fibrous and insoluble structural protein extensively crossed-linked with disulphide bond, hydrogen bond, hydrophobic interaction, resulting in the mechanical stability, of keratin and resistance to common proteolytic enzyme like as pepsin, trypsin and papain (Onifad et al., 1998). Proteases constitute one of the most important groups of enzyme and their annual sales account for 
$60 \%$ of the world enzyme market (Turk 2006). Keratinase (E.C.3.4.95\%) belongs to the class hydrolase which are able to hydrolyze insoluble keratins more efficient than other protease (Vigneshwaran et al., 2010). Feather degrading keratinase producing bacteria are Bacillus licheaifoemis (Zerdaniet al., 2004). There are several reports that show Streptomyces produces keratinase enzyme e.g. S.albidoflavus (Bressolieret al., 1999). Streptemces spp., 5a4 (DeAzeredoet al., 2006) and Streptomyces spp.,.CN 902 (Lazimetal; 2009). Keratinolytic activities were also demonstrated in saprophytic fungi like as Acta Mycologia (Kornillowicz, 1994).

In this study we identified Streptomyces coelicoflavus and then partially purified and characterized the secreted keratinase enzyme. The ability of this enzyme to degrade keratin based substrates selectively which was greater than the ability of other Streptomyces spp.

\section{Materials and Methods}

\section{Materials}

Soil sample: 8 Soil samples were collected from the sangli district M.S., India and used for isolation of Actinomycetes.

Glycerol aspargine broth and Glycerol aspargine agar with cycloheximed(80 $\mu \mathrm{g} / \mathrm{ml})$. Skimmed milk agar, Basal salt medium, Feather meal agar, Gelatine agar, Christensen's medium, Egg yolk agar, PYIA, Peptone water, Starch agar, Peptone nitrate broth, Sugar fermentation medium. Keratin solution.

Buffer: Acetate Buffer (pH- 4 to 5.5), Phosphate Buffer (pH- 6 to 7.5), Tris- $\mathrm{HCl}$ Buffer (pH -8 to 9).
Metal: $\mathrm{Zn}^{++}, \mathrm{Mg}^{++}, \mathrm{Cu}^{++}, \mathrm{Mn}^{++}, \mathrm{Ca}{ }^{++}$. Reducinag and inhibitory agents: 1,10 Phenanthroline, SDS, EDTA, Sodium Sulphied, Dithiothreitol(DTT). Dimethyl Sulfoxide, Acetone, Trichloroacetic acid, Bradford reagent.

\section{Methods}

\section{Isolation of Actinomycetes}

The soil samples were collected from the villages around Shirala, Dist.-Sangli, M.S. India and enrichment of soil samples were carried out in Glycerol asparagine broth supplemented with Cycloheximide $(80 \mu \mathrm{g} / \mathrm{ml})$. A 10 -fold serial dilutions of the sample were prepared up to $10^{-6}$ and $0.1 \mathrm{ml}$ aliquots of $10^{-5}$ and $10^{-6}$ dilution was inoculated into Glycerol asparagine agar (Lasparagine- $0.1 \mathrm{~g}, \mathrm{~K}_{2} \mathrm{HPO}_{4}-0.1 \mathrm{~g}$, glycerol$1 \mathrm{~g}$, trace salt solution- $0.1 \mathrm{ml}$, agar- $2.5 \mathrm{~g}$, distilledwater-100 $\mathrm{ml} \mathrm{pH-7.4).} \mathrm{To} \mathrm{avoid} \mathrm{the}$ growth of fungal contaminant, medium was supplemented with Cycloheximide $(80 \mu \mathrm{g} / \mathrm{ml})$. Plates were incubated at room temperature and monitored periodically over 5 to 7 days. Pure isolates were transferred to slants of Glycerol asparagine agar and preserved at $4{ }^{\circ} \mathrm{C}$ for further study.

\section{Identification of Isolate}

Morphological characteristics were studied with cover slip culture technique. Cultural characteristics were recorded on Glycerol asparagine agar medium. Biochemical characters were recorded on the basis of sugar utilization potential, enzymatic activities and growth under inhibitory substances. On the basis of spore mass color, the substrate mycelium color, the shape of the spore chain, morphological and cultural characteristics the isolate were tentatively identified as Streptomyces. Biochemical characterisations of 
Streptomyces producing keratinase were carried out (Williams et al., 1983)

\section{Primary Screening}

The primary screening of Keratinolytic Streptomyces were carried on Skimmed milk agar plates $(\mathrm{pH}$ 6.5-7.2) containing peptone$1 \%$, sodium chloride- $0.5 \%$, yeast extract$0.3 \%$, agar- $2 \%$ and skim milk-10\%. All the plates were incubated at $30^{\circ} \mathrm{C}$ for $2-5$ days. After incubation, the plates were observed for the zone of clearness around the colony.

\section{Secondary Screening}

Keratinolytic Streptomyces were screened on keratin basal salt agar. (Ghosh et al., 2008).

\section{Molecular Identification of Streptomyces}

One of the potent keratinase producing Streptomyces was identified by using 16SrRNA Sequencing. Name of the primer used for forward sequencing was $27 \mathrm{~F}$ with sequence details AGAGTTTGATCMTG GCTCAG having number of Base 20. Name of the primer used for reverse sequencing was 1492R with sequence details TACGGYTACCTTGTTACGACTT having number of Base 22. 16S rRNA gene fragment was amplified using universal primers such as above mentioned. The phylogeny analysis of sequence with the closely related sequence of blast results was performed followed by multiple sequence alignment.

\section{Preparation of Crude Enzyme}

Keratinolytic Streptomyces colony was transfer on basal salt medium containing feather meal and kept for incubation at $35^{\circ} \mathrm{C}$ for 120 to $160 \mathrm{hrs}$. with shaking at $200 \mathrm{rpm}$. The feather meal broth was mixed thoroughly with a $50 \mathrm{ml}$ tris- $\mathrm{HCl}$ buffer (50mM, pH 8). The mixture was shaken for $30 \mathrm{~min}$ at room temperature in an orbital shaker (155strokes/min) and the process was repeated two to three times. The filtrate thus obtained was used as a crude enzyme for protease activity (Ponnuswamy et al., 2012; Vigneshwaran et al., 2010).

\section{Preparation of Keratin solution}

Keratinolytic activity was measured with soluble keratin $(0.5 \% \mathrm{w} / \mathrm{v})$ as substrate. Soluble keratin was prepared from white / black chicken feat hers by the method of Wawrzkiewicket al.,(1997). Native chicken feathers $(10 \mathrm{gm})$ in $500 \mathrm{ml}$ of dimethyl sulfoxide were heated in a hot air oven at $100^{\circ} \mathrm{C}$ for $2 \mathrm{hrs}$. Soluble keratin was then precipitated by addition of cold acetone (1L) at Freezer temperature for $2 \mathrm{hrs}$, followed by centrifugation at $10,000_{\mathrm{Xg}}$ for $10 \mathrm{~min}$. The precipitate was washed two times with distilled water and dried at $40^{\circ} \mathrm{C}$ in a vacuum dryer. $1 \mathrm{gm}$ of quantified precipitate was dissolved in $20 \mathrm{ml}$ of $0.05 \mathrm{M} \mathrm{NaOH}$. The $\mathrm{pH}$ was adjusted to 7.0 with $0.1 \mathrm{M} \mathrm{HCl}$ and the solution was diluted to $200 \mathrm{ml}$ with $0.05 \mathrm{~mol} / \mathrm{L}$ Phosphate buffer( $\mathrm{pH}$ 7.0) (Vigneshwaran et al., 2010).

\section{Keratinase Assay}

Keratinase activity was determined by the method as described by Krishna Rayudu (2014) with modification. $2 \mathrm{ml}$ of reaction mixture contain of $1 \mathrm{ml}$ of keratin solution and $1 \mathrm{ml}$ crude enzyme of supernant and then reaction mixture incubated for $10 \mathrm{~min}$. at 40 ${ }^{0} \mathrm{Cin}$ shaking water bath at $100 \mathrm{rpm}$ agitation. $2 \mathrm{ml}$ of $(10 \%)$ chilled TCA was added and the mixture was kept for $20 \mathrm{~min}$., followed by centrifugation $5000 \mathrm{rpm}$ for 10 min. $0.1 \mathrm{ml}$ of the supernant was added with $0.9 \mathrm{ml} \mathrm{D} / \mathrm{W}$ and $0.5 \mathrm{ml}$ of $500 \mathrm{mM}$ sodium carbonate and incubated $35^{\circ} \mathrm{C}$ for $10 \mathrm{~min} .2$ 
$\mathrm{ml}$ Folin-Ciocalteu reagent $(1: 3 \mathrm{v} / \mathrm{v})$ was added and incubated for $20 \mathrm{~min}$. followed by reading absorbance at $660 \mathrm{~nm}$ for the developed blue color. A control was processed by adding the enzyme after incubation and TCA was immediately added. A standard graph was generated using standard tyrosine solution of 10$100 \mu \mathrm{g} / \mu \mathrm{l}$. One unit of keratinolytic activity is defined as the amount of enzyme that librates $1 \mu \mathrm{g}$ of tyrosine equivalent per min. under the described assay condition.

\section{Protein Determination}

Protein contain was measured by the method of Bradford (1976) using bovin serum albumin (BSA) as standard.

\section{Amino acid analysis by HPLC}

The method of amino acid analysis of Robert and Stephen (1984) and Jeong et al.,(2010) was used to determine the amino acid contents for feather degradation broth. High Performance Liquid Chromatography (HPLC) was used for amino acid analysis. In this technique quantified the amino acids by using phenylisothiocynate (PITC) as a coupling reagent. The quantitative pre column derivatization of amino acids and several reverse phase HPLC systems for separation of the resulting phenylthiocarbamyl (PTC) derivatives. During the process, $3.5 \mu \mathrm{l}$ Agilent columns $(4.6 \times 150$ $\mathrm{mm}$ ) were employed.

\section{Activity of keratinase with different Parameters}

\section{Effect of pH}

The optimum $\mathrm{pH}$ was determined at $40^{\circ} \mathrm{C}$ for $1 \mathrm{hrs}$. Using following buffers $(50 \mathrm{mM} / \mathrm{l})$ : Sodium phosphate buffer ( $\mathrm{pH}$ 6-7.5), Tris$\mathrm{HCl}$ buffer ( $\mathrm{pH} 7.5-9)$.

\section{Effect of Temperature}

To determine optimum temperature for keratinolysis, enzyme reaction carried out at different temperature for $1 \mathrm{hrs}$. Temperature ranging Acetate Buffer ( $\mathrm{pH}-4$ to 5.5), from $30^{\circ} \mathrm{C}$ to $50^{\circ} \mathrm{C}$ were used. Enzyme activity was determined by standard enzyme assay.

\section{Effect of metal divalent ion}

Five metal divalent ion were used to determine effect on keratinase activity, such as $(5 \mathrm{mM}) \mathrm{Ca}++, \mathrm{Zn}++, \mathrm{Cu}++, \mathrm{Mn}++, \mathrm{Mg}++$ activity of metal an keratinase was determined by standard enzyme assay.

\section{4)Effect of reducing agent and inhibitors}

The effect of SDS, sodium sulphide, dithiothretol (DTT), 1,10phenanthroline and EDTA on enzymolytic activity was determined. A control was kept with the enzyme and the substrate (without above agent) and the value of the control activity was consider as $100 \%$

\section{Results and Discussions}

\section{Isolation of Keratinolytic Streptomyces}

A total 14 caseinase producing isolates were screened and used in feather meal basal salt agar medium for feather degrading property it was found that the SH1strain was shown feather degradation at $30^{\circ} \mathrm{C}$ within $94 \mathrm{hrs}$. The isolate SH1 strain belonging to genus Streptomyces was tentatively identified on the basis of morphological and biochemical characteristics were studied (Table 1).

\section{Identification of Streptomyces}

On the basis of morphological and biochemical characteristic (Table 1) the isolate, was identified up to the genus level 
and using 16s rRNA sequence the isolates further identified up to species Streptomyces coelicoflavus.

\section{Degradation of Feather}

Streptomyces coelicoflavusLC072737 was able to grow and produce keratinase in feather meal basal salt brothmedium (Cai et $a l .$, ) and resulted in maximum degradation of feather after 7 days incubation at $40^{\circ} \mathrm{C}$ at $150 \mathrm{rpm}$ (fig.5). Keratinase activity measured was $49 \mathrm{U} / \mathrm{ml}$ in the absorbance at $660 \mathrm{~nm}$ by standard enzyme assay method (Rayudu, 2014)

Amino acids analysis from feather degradation broth of Streptomyces coelicoflavus was quantified by High Performance Liquid Chromatography (HPLC). During the process Agilent columns $(4.6 \times 150 \mathrm{~mm}) \quad 3.5 \mu \mathrm{l}$ were employed.

A total 18 amino acids were found in the feather degradation broth. Cysteine was found in high concentration $(3.3569 \mu 1 / \mathrm{ml})$ followed byleucine $(2.02558 \mu \mathrm{l} / \mathrm{ml})$. Total concentration of amino acid in broth was found $13.4986 \mu 1 / \mathrm{ml}$. In feather degradation broth released essential amino acids such as threonine $(0.4140 \mu \mathrm{l} / \mathrm{ml})$, methionine $(1.7487 \mu \mathrm{l} / \mathrm{ml}), \quad 1$-methyl histidine $(0.5909 \mu \mathrm{l} / \mathrm{ml})$ and lysine $(1.4014 \mu \mathrm{l} / \mathrm{ml})$.
Saha (2012) and Rayudu (2014) reported 15 and 16 amino acids from feather degradation broth respectively.

\section{Activity of keratinase with different parameters}

\section{Effect of pH}

The enzyme keratinase was active in $\mathrm{pH} 6$ to $\mathrm{pH}$ 9. Enzyme has an optimum $\mathrm{pH}$ 8. The enzyme activity was high for alkaline $\mathrm{pH}$, similar finding was reported in Streptomyces spp. (Azeredo et al., 2006). Increasing activity were reported as there is increase in $\mathrm{pH} 6$ to 8 and reduced slightly from $\mathrm{pH} 8$ to 9.

\section{Effect of Temperature}

The effect of temperature on keratinase catalytic activity of enzyme increased with increasing temperature up to $40^{\circ} \mathrm{C}$ and beyond $40^{\circ} \mathrm{C}$ reduced the enzyme activity. Similar results were also reported by Jaouadi et al., in 2010 of Streptomyces spp., strain AB1. Similar kind of properties were studied on $S$. thermoviolaceus (Chitte, 1999), B. subtilis (Setyorine et al., 2006), Streptomyces spp., (Tapia and Simoes2008), B. Licheniformis (Vigneshwaran2010). Some microorganism show optimum activity at the temperature of $60^{\circ} \mathrm{C}$.

Fig.1 Spore chain morphology under light microscope (isolate SH1)

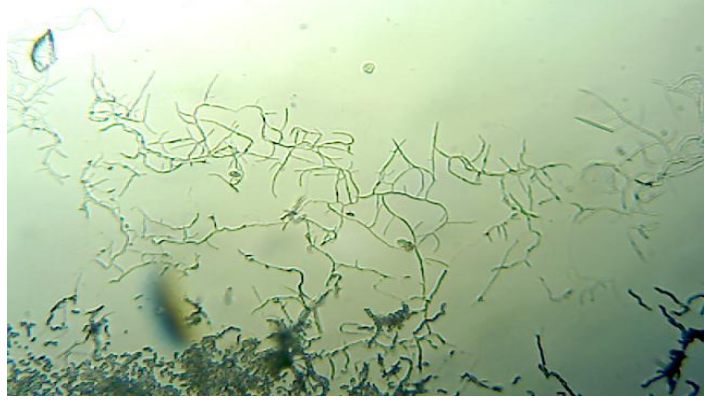


Table.1 Characterization of isolate 2(SH1) (Williams et al., 1983a)

\begin{tabular}{|c|c|c|c|c|}
\hline \multirow{2}{*}{\begin{tabular}{|l|} 
Sr. \\
No. \\
1
\end{tabular}} & \multicolumn{3}{|l|}{ Characteristic } & \multirow{2}{*}{$\begin{array}{l}\text { Resul } \\
+\end{array}$} \\
\hline & $\begin{array}{l}\text { Morphological } \\
\text { Characters }\end{array}$ & \multicolumn{2}{|c|}{$\begin{array}{l}\text { Spore chain morphology } \\
\text { (spirals) }\end{array}$} & \\
\hline 2 & $\begin{array}{l}\text { Pigmentation } \\
\text { Characters }\end{array}$ & \multicolumn{2}{|c|}{$\begin{array}{l}\text { Pigmentation on PYIA } \\
\text { (Blackish brown) }\end{array}$} & + \\
\hline \multirow[t]{6}{*}{3} & \multirow{6}{*}{$\begin{array}{l}\text { Carbon } \\
\text { Utilization }\end{array}$} & \multicolumn{2}{|l|}{ Glucose } & + \\
\hline & & \multicolumn{2}{|l|}{ Sucrose } & + \\
\hline & & \multicolumn{2}{|l|}{ Mannitol } & + \\
\hline & & \multicolumn{2}{|l|}{ Xylose } & + \\
\hline & & \multicolumn{2}{|l|}{ Arabinose } & + \\
\hline & & \multicolumn{2}{|l|}{ Lactose } & - \\
\hline \multirow[t]{4}{*}{4} & \multirow{4}{*}{$\begin{array}{l}\text { Nitrogen } \\
\text { utilization }\end{array}$} & \multicolumn{2}{|c|}{ L-phenylalanine } & \\
\hline & & \multicolumn{2}{|l|}{ L-Cysteine } & - \\
\hline & & \multicolumn{2}{|l|}{ L-Histidine } & + \\
\hline & & \multicolumn{2}{|l|}{ DL-Valine } & + \\
\hline \multirow[t]{10}{*}{5} & \multirow{10}{*}{$\begin{array}{l}\text { Enzyme } \\
\text { activity }\end{array}$} & \multicolumn{2}{|l|}{ Catalase } & + \\
\hline & & \multicolumn{2}{|l|}{ Oxidase } & + \\
\hline & & \multicolumn{2}{|l|}{ Lecithinase } & + \\
\hline & & \multicolumn{2}{|l|}{ Lipolysis } & + \\
\hline & & \multicolumn{2}{|l|}{ Protease } & + \\
\hline & & \multicolumn{2}{|c|}{ Nitrate reductase } & + \\
\hline & & \multicolumn{2}{|l|}{ Gelatinase } & + \\
\hline & & \multicolumn{2}{|l|}{ Amylase } & + \\
\hline & & \multicolumn{2}{|l|}{ Urease } & 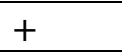 \\
\hline & & $\mathrm{H} 2 \mathrm{~S}$ producti & & - \\
\hline 6 & & $4^{0} \mathrm{C}$ & & - \\
\hline & & $10^{\circ} \mathrm{C}$ & & - \\
\hline & Growth & $37^{\circ} \mathrm{C}$ & & + \\
\hline & Temperatures & $50^{\circ} \mathrm{C}$ & & - \\
\hline 7 & & Crystal violet & $0.0001 \%)$ & - \\
\hline & Growth in & Phenol $(0.1 \%$ & & + \\
\hline & presence of & Sodium azide & $0.001 \%$ & + \\
\hline & inhibitory & & $0.002 \%$ & - \\
\hline & compounds & Sodium & $4 \%$ & + \\
\hline & & chloride & $7 \%$ & - \\
\hline
\end{tabular}

* Where $+=$ positive $-=$ negative 
Table.2 Amino acids from feather degradation using Streptomyces coelicoflavus in basal salt broth medium

\begin{tabular}{|l|l|l|}
\hline Sr.No. & Amino acids & $\boldsymbol{\mu g} / \mathbf{m l}$ of sample \\
\hline 1 & Aspartic acid & 0.47547 \\
\hline 2 & OH Proline & 0.34055 \\
\hline 3 & Phosphoenolamine & 0.1993 \\
\hline 4 & Serine & 0.30448 \\
\hline 5 & Aspargine & 0.27947 \\
\hline 6 & Taurine & 0.76002 \\
\hline 7 & Threonine & 0.4140 \\
\hline 8 & Proline & 0.2004 \\
\hline 9 & Arginine & 1.0853 \\
\hline 10 & $1-$ Methyl histidine & 0.59093 \\
\hline 11 & Tyrosine & 0.29792 \\
\hline 12 & Valine & 0.07203 \\
\hline 13 & Methionine & 1.74876 \\
\hline 14 & Cystathionine & 0.09125 \\
\hline 15 & Cysteine & 3.35692 \\
\hline 16 & Leucine & 2.02558 \\
\hline 17 & Phenylalanine & 0.25544 \\
\hline 18 & Lysine & 1.40148 \\
\hline & Total & $\mathbf{1 3 . 4 9 8 6}$ \\
\hline
\end{tabular}

Table.3 Effect of metal on enzyme activity

\begin{tabular}{|l|l|l|l|}
\hline \multirow{2}{*}{ Sr. No. } & Divalent ions & Concentration & Relative activity (\%) \\
\cline { 2 - 4 } & Control & - & 100 \\
\hline 1 & $\mathrm{Ca}^{++}$ & $5 \mathrm{mM}$ & 108 \\
\hline 2 & $\mathrm{Zn}^{++}$ & $5 \mathrm{mM}$ & 101 \\
\hline 3 & $\mathrm{Mg}^{++}$ & $5 \mathrm{mM}$ & 108 \\
\hline 4 & $\mathrm{Cu}^{++}$ & $5 \mathrm{mM}$ & 101 \\
\hline 5 & $\mathrm{Mn++}$ & $5 \mathrm{mM}$ & 101 \\
\hline
\end{tabular}

Fig.2 Spore chain morphology and arrangement under SEM

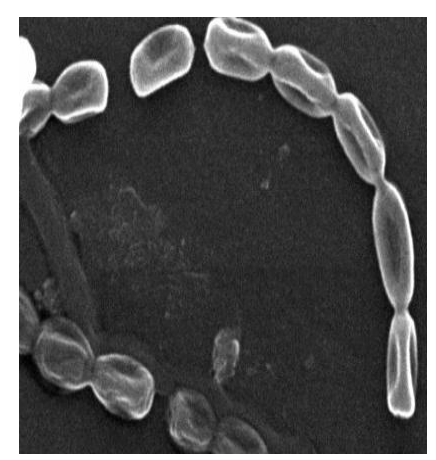


Table.4 Effect of Reducing agent and inhibitors on enzyme activity

\begin{tabular}{|l|l|l|l|}
\hline \multirow{2}{*}{ Sr. No. } & Reducing Agent & Concentration & Relative activity (\%) \\
\cline { 2 - 4 } & Control & - & 100 \\
\hline 1 & $\begin{array}{l}\text { Dithiotreitol } \\
(\text { DTT })\end{array}$ & $5 \mathrm{mM}$ & 101 \\
\hline 2 & SDS & $5 \mathrm{mM}$ & 109 \\
\hline 3 & Sodium sulphide & $5 \mathrm{mM}$ & 111 \\
\hline 4 & DMSO & $5 \mathrm{mM}$ & 111 \\
\hline & Inhibitors & & 106 \\
\hline 5 & $\begin{array}{l}1,10 \\
\text { Phenanthroline }\end{array}$ & $5 \mathrm{mM}$ & 105 \\
\hline 6 & EDTA & $5 \mathrm{mM}$ & \multicolumn{2}{|l}{} \\
\hline
\end{tabular}

Fig.3 Clear zone around colony in Skimmed milk agar (isolate SH1).

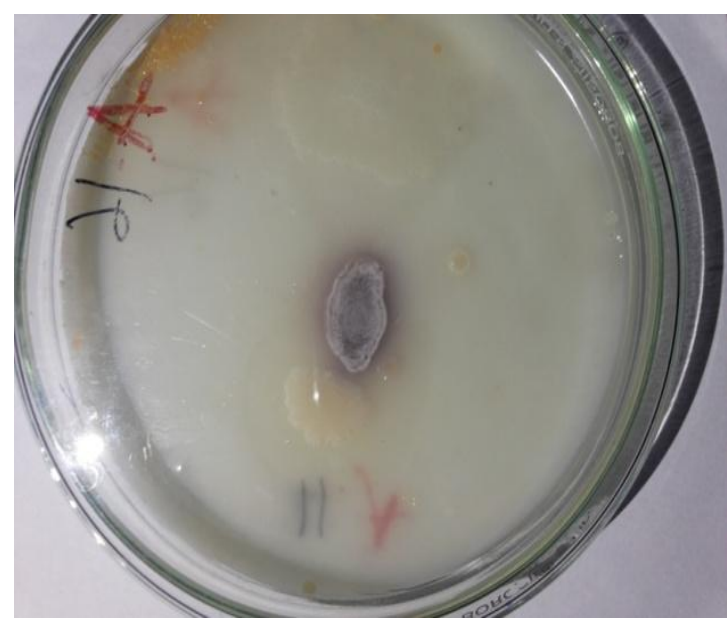

Phylogenic tree

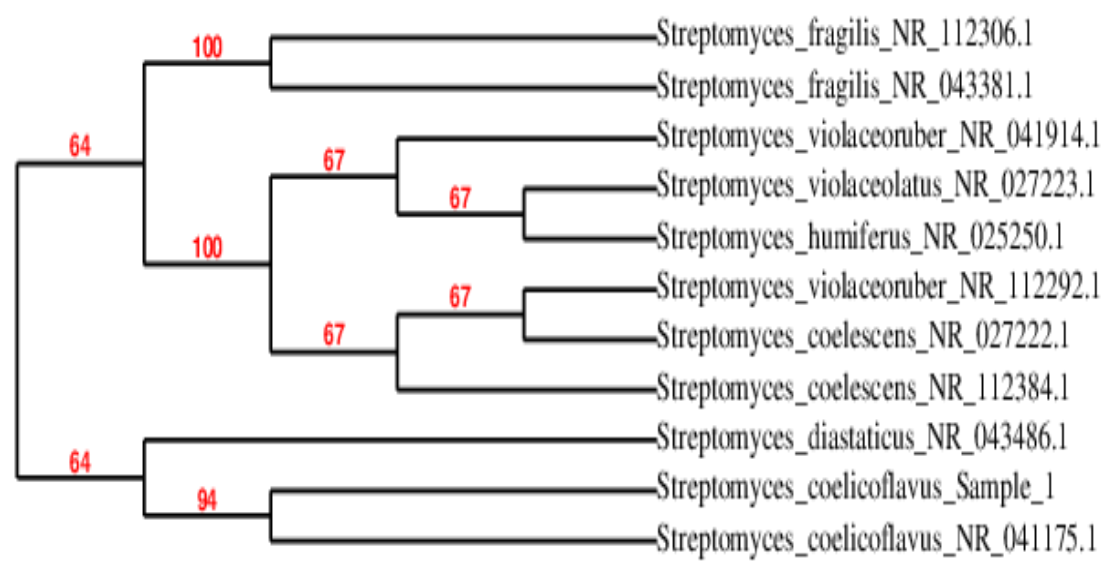


Fig.5 Chromatogram of HPLC (reverse phase) Amino acid analysis.

\section{Amino acid analysed by HPLC}

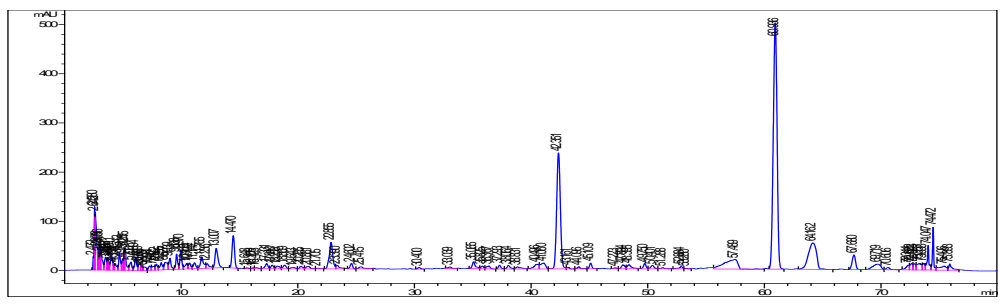

Fig.6 Effect of pH

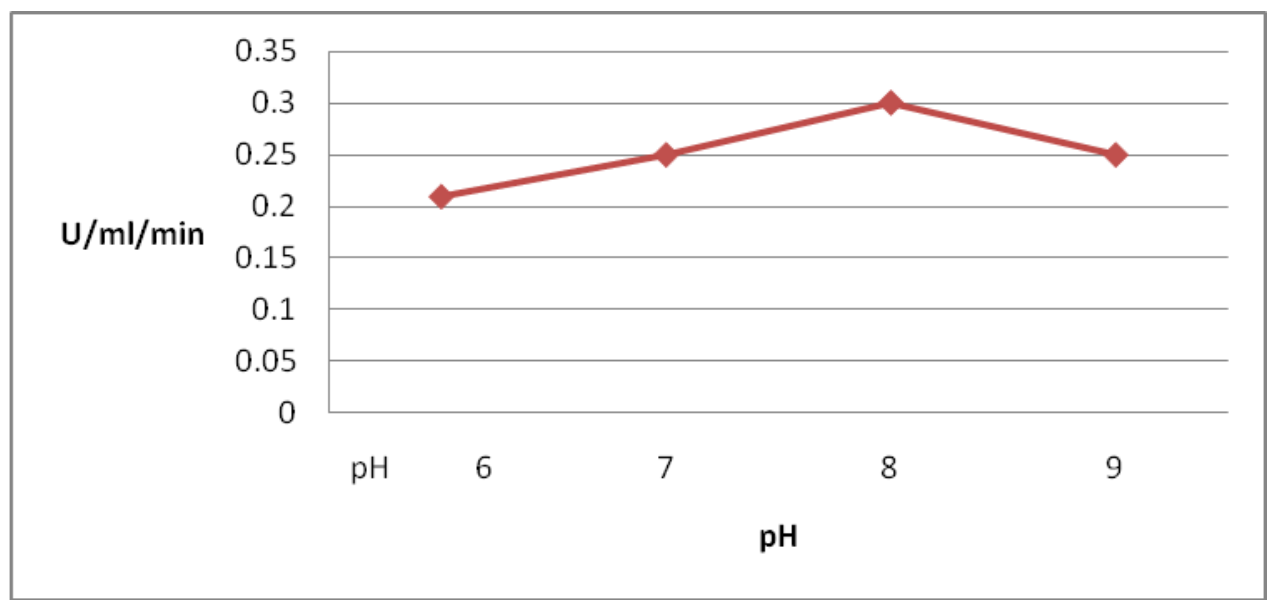

Fig.7 Effect Temperature

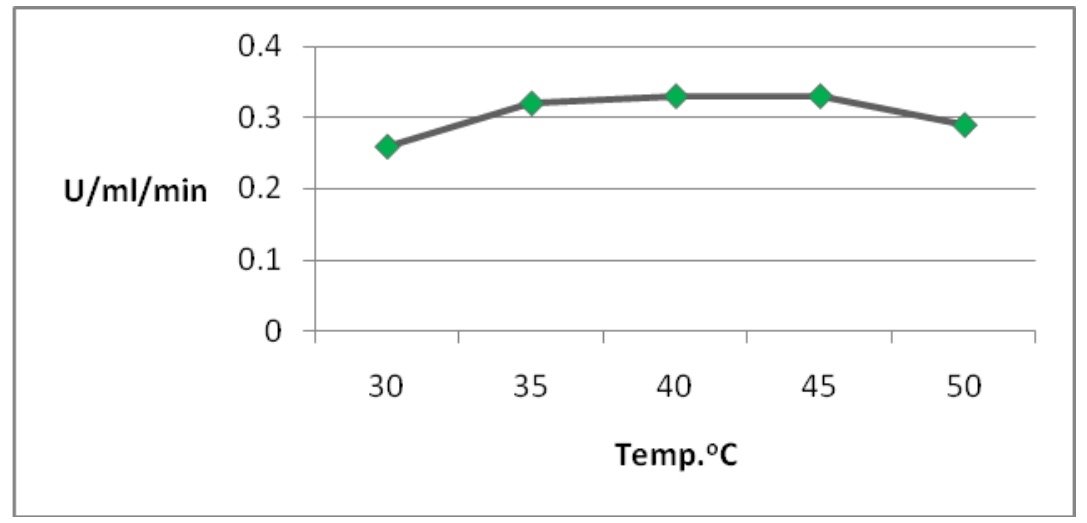

Effect of Divalent ion on enzyme activity

The result of enzyme activity of keratinase towards divalent ion $(5 \mathrm{mM})$ such as $\mathrm{Ca}^{++}, \mathrm{Zn}^{++}, \mathrm{Mg}^{++}, \mathrm{Cu}^{++}, \mathrm{Mn}^{++}$, were stimulatory. The effect of heavy metal ions such as $\mathrm{Cu}^{++}$(Nam et al., 2002), $\mathrm{Mn}^{++}, \mathrm{Mg}^{++}$ on B. subtilis $\mathrm{KD}-\mathrm{N}_{2}$ strain was similarly reported by Bockel et al., (1995).

Effect of Reducing agent and Inhibitors on keratinase enzyme

The keratinase activity was partially affected 
by reducing agent Dithiotreitol (DTT) at a concentration 5mM. Sodium sulphide enhance the keratinase activity throughout the cleavage of disulphide bond reported by Letourneau in 1988. The SDS, 1,10Phenanthroline and EDTA (each 5mM) enhance effect on keratinase but less than sodium sulphide and DMSO. Similar results were observed by Streptomyces pactum DSMS 40536 (Bockle et al., 1995).

In conclusion, according to these results, we conclude that the Keratinolytic proteainase of Streptemces coelicoflavus LC072737 might be suitable for processing of keratinase containing waste like feather and hairs in leather industry under appropriate conditions. The crude keratinase was active at broad range of temperature $\left(30^{\circ} \mathrm{C}\right.$ to $50^{\circ} \mathrm{C}$ ) and $\mathrm{pH}$ values (6 to 9) with optima at $40^{\circ} \mathrm{C}$ and $\mathrm{pH} 8$.

\section{Acknowledgement}

Researchers are thankful to the Principal of Shriman Bhausaheb Zadbuke Mahavidyalaya, Barshi Dist. Solapur for laboratory and library facilities to carry out this study and also thankful tothe Principal of Vishwasrao Naik Arts, Commerce and Baba Naik Science Mahavidyalaya, Shirala. Dist. Sanglifor Laboratory facilities to carry out this study.

\section{References}

Agraharisarita, Neerajwadhawa. 2010. Degradation of chicken feather a poultry waste product by Keratinolytic bacteria isolated from dumping site at ghazipur poultry processing plant. Int. J. Poultry Sci., 9(5): 482-489.

Bockle, B., Galunsky, B., Muller, R. 1995. Characterization of Keratinolytic serine proteinase from Streptomyces pactum DSM 40530. Appl. Environ. Microbial., 61: 3705-3710.
Bradford, M.M. 1976. Arapidand sensitive method for quantitation of microgram quantities of protein utilizing the principal of protein dye binding .Anal. Biochem., 72(12): 248-254, doi:10.1016/0003-2697(76)90557-3.

Bressollier, P., Letourneau, F., Urdaci, M., Verneuil, B. 1999. Purification and characterization of a keratinolytic serine proteinase from Streptomyces albidoflavus. Appl. Environ. Microbiol., 65: 2570-2576.

Cai, C.G., Zheng, X.D. 2008. Keratinase production and keratin degradation by a mutant strain of Bacillus subtilis. J. Zhejiang Univsci B., 9: 60-67.

Chitte, R.R., Nalawade, V.K., Dey, S. 1999. Keratinolytic activity from the broth of a feather-degrading thermophilic Streptomyces thermoviolaceus strain SD8. Lett. Appl. Microbiol., 28: 131136.

De Azeredo, L.A.I., De Lima, M.B., Coelho, R.R.R., Freire, D.M.G. 2006. Thermophilic protease production by Streptomyces spp. 594 in submerged and solid-state fermentations using feather meal. J. Appl. Microbiol., 100(4): 641-647.

Ghosh, A., Chakrabarti, K., Chattopadhyay, D. 2008. Cloning of feather degrading minor extracellular protieases from Bacillus cereus DCUW: dissection of the structural domains. Microbiol., 155: 2049-2057.

Jaouadi, B., Abdelmalek, B., Fodil, D., Ferradji, F.Z., Rekik, H., Zarai, N. 2010. Purification and characterization of a thermostablekeratinolytic serine alkaline proteinase from Streptomyces spp. Strain AB1 with high stability in organic solvents. Bioresour. Technol., 101: 8361-8369.

Kornillowicz, T. 1994. Method for determining Keratinolytic activity of saprophytic fungi, Actamycologia, 29(2): 169-178.

Kumar mukesh, D.J., Lavanya, S., Priya, P. 2012. Production of feather protein 
concentrate from feathers by In vitro enzymatic treatment, its biochemical characterization and antioxidant nature. Middle-East J. Scientific Res., 11(7): 881-886.

Lazim, H., Mankai, H., Slama, N., Barkallah, I., Limam, F. 2009. Production and optimization of thermophilic alkaline protease in solid state fermentation by Streptomyces spp., CN902. J. Microbiol. Biotechnol., 36(4): 531-537.

Onifade, A.A., Al-sane, N.A., Al-Musallam, A.A., AL-zardan, S. 1998. A review: potential for biotechnological application of keratin degrading microorganism and their enzyme for nutritional improvement of feathers and other keratins as livestock feed resources. Bioresour. Technol., 66: 111.

Ponnuswamy Vijayraghavan, Lavanya, J., Samuel gnanaprakash Vincent. 2012. Biosynthesis and characterization of keratinilytic protease from Actinobacterium spp., in solid state culture. Inter. Jr. of Appl. Biol. Pharma. Tech., 3(2): 149- 158.

Pushpalata, S.K., Naik, G.R. 2010. Production and characterization of feather Degrading keratinase from Bacillus Spp. JB 99.Indian J. Biotechnol., 9: 384-390.

Rayudu Krishna, Jayaraj. Y.M. 2014. Biodegradation of poultry feather by novel Keratinolytic bacteria isolates of North-East Karnataka, Ph.D. Thesis.

Saha Subhasish, Dhanasekaran, D. 2012. Exploration of Keratinolytic
Actinobacteria for the bioconversion of poultry feather waste into poultry feed supplement, Ph.D. Thesis.

Setyorine, E., Takenaka, S., Murakami, S., Aoki, K. 2006. Purification and characterization of two novel halotolerant extracellular protease from Bacillus subtilis strain FP-133. Bioscience. Biotechnol. Biochem., 70(2): 433-440.

Tapia, D.M.T., M.L.G. Simoes. 2008. Production and partial characterization of keratinase produced by a microorganism isolated from poultry processing plant wastewater. Afr. J. Biotechnol., 7: 296-300.

Turk, B. 2006. Targeting protease: Successes failures and feature prospects. Nature Reviews Drug Discovery, 5: 785-798.

Vigneshwaran, C., Shanmugam, S., Satishkumar, T. 2010. Screening and characterization of keratinase from Bacillus licheniformis isolated from namakkal poultry farm, 2(4).

Wawrzkiewicz, K., Wolski T., Lobarzewski, J. 1991. Screening the keratinolytic activity of dermatophytes in vitro. Mycophthologia, 114: 1-8.

Williams, S.T., Goodfellow, M., Alderson, G., Wellington, E.M.H., Sneath, P.H.A. and Sackin, M.J. 1983a. Numerical classification of Streptomyces and related genera. J. General Microbiol., 129: 1743-1813.

Zardani, I.M., Faid, Malki, A. 2004. Feather wastes digestion by new isolated strainsBacillusspp., In Morocco. Afr. J. Biotechnol., 3: 67-70.

\section{How to cite this article:}

Jadhav, R.S., D.D. Karad and Kulakrni, S.W. 2016. Isolation, Identification and Characterization of Keratinolytic Streptomyces coelicoflavus. Int.J.Curr.Microbiol.App.Sci. 5(7): 153-163. doi: http://dx.doi.org/10.20546/ijcmas.2016.507.015 